\title{
ROHINGYA'S IN SEARCH FOR SECURITY: AN INTRODUCTION TO HUMAN SECURITY CONCEPT THROUGH ROHINGYA' LENS
}

\author{
Riana Mardila \\ UIN Syarif Hidayatullah Jakarta \\ Email: riana.mardila@uinjkt.ac.id
}

\begin{abstract}
It is now 48 years from the declaration of 1982 Burma Citizenship Law. A law that legally denied the citizenship of (Muslim) Rohingya in Myanmar. It means also that for 48 years (Muslim) Rohingya remains stateless. Their fight over citizenship then becomes a global, or at least a regional challenge in International Relations sphere. In one aspect, their attempt in finding asylum to other countries at some point threaten the (arrival) state' security. However, in another side, they also fight for their (human) security or even so (human)rights. Both securities are equally important. This article is more an introduction to the Human Security concept that was first initiated in 1994. It starts with a simple question on "how does Human Security explain the issue of Rohingya?" It seeks for key points that Human Security can explain by reflecting on Rohingya as the case study. It aims to give a bigger picture of this conflict interpreted by Human Security concept. Finally, as we are living in the globalization era, this issue is not only a state or regional challenge, but also a global challenge where IR actors can take responsibilities in helping and solving this human insecurity issue.
\end{abstract}

Keywords: Rohingya; Human Security.

\begin{abstract}
Abstrak. Telah berlangsung 48 tahun sejak deklarasi Undang-undang Kewarganegaraan Burma 1982. Sebuah undangundang yang secara hukum menolak kewarganegaraan (Muslim) Rohingya di Myanmar. Itu juga berarti bahwa selama 48 tahun (Muslim) Rohingya tetap tanpa kewarganegaraan. Perjuangan mereka atas kewarganegaraan kemudian menjadi tantangan global, atau setidaknya tantangan regional dalam ranah Hubungan Internasional. Di satu aspek, upaya mereka untuk mencari suaka ke negara lain pada titik tertentu mengancam keamanan (kedatangan) negara. Namun di sisi lain, mereka juga memperjuangkan keamanan (manusia) atau bahkan lebih (hak asasi manusia). Kedua sekuritas itu sama pentingnya. Artikel ini lebih merupakan pengenalan tentang konsep Keamanan Manusia yang pertama kali dimulai pada tahun 1994. Artikel ini dimulai dengan pertanyaan sederhana tentang "bagaimana Keamanan Manusia menjelaskan masalah Rohingya?" Ini mencari poin-poin penting yang dapat dijelaskan oleh Human Security dengan merefleksikan Rohingya sebagai studi kasus. Hal ini bertujuan untuk memberikan gambaran yang lebih besar tentang konflik yang ditafsirkan oleh konsep Human Security. Terakhir, saat kita hidup di era globalisasi, masalah ini tidak hanya menjadi tantangan negara atau regional, tetapi juga tantangan global di mana para aktor IR dapat mengambil tanggung jawab dalam membantu dan menyelesaikan masalah ketidakamanan manusia ini.
\end{abstract}

Kata Kunci. Rohingya; Keamanan Manusia. 


\section{Introduction}

Bali $(2008,480)$ says "as long as the world is fulfilled with repression, conflict, political and economic inequality, then population movements are inevitable." It describes Muslim Rohingya well. They are refused by the Bangladesh government. They are also discriminated by the Burmese. As it is declared in the 1982 Burma Citizenship Law, Rohingya does not belong to the Burmese ethnicities (Human Rights Watch (HRW) 2000). Hence, they do not have rights to be legally protected by the Burmese government. This law then 'force' them to illegally move outside Burma to seek for a safer and proper asylum.

In a bigger picture, this is not only about an issue of illegal-undocumented people movements. This is also about the fact that Rohingya is stateless caused by the legal law; a law that is coincidentally created to justify the violation of Rohingya security. News reported that 1.1 million Rohingya in Myanmar are stateless (Mclaughlin, 2015) and 140,000 of them were displaced as the consequences of the deadly clashes against Buddhist in 2012 (Human Rights Watch (HRW) 2015).

Ironically, since 1994 United Nations Development Report has promoted the concept of Human Security. When it was first initiated, its values were expected to shift the security paradigm from state-centric to people centric. It promotes that human should be free: 'free from fear, free from want, and free to live in dignity.' Two decades after its first initiation, Human Security Unit (HSU) even set a goal expecting that Human Security should be mainstreamed as a framework in all aspect and all level of the international system (HSU 2014, 14).

However, reflecting the conflict of Rohingya, this shows that this concept is still a discourse. True, if people argue that the Burma Citizenship Law was established in 1982, 14 years before the born of Human Security concept itself. However, the fact that Rohingya up to now does not free from fear, not free from want, and not free to live in dignity, indicates that it calls the transformation of Human Security as a study to the implemented policy. It also implies that "empowerment and protection" as the approaches of Human Security are still being marginalized.

This essay starts with a simple question "how does Human Security explain the issue of Rohingya?" It would not seek for what went wrong with this case so then it persists. Yet, It seeks for key points that Human Security can explain by reflecting on Rohingya as the case study. It aims to give a bigger picture of this conflict interpreted by Human Security concept. First, it describes the Rohingya insecurity that shows the absence of human security in Myanmar. It includes facts and numbers from news and recent report. It also mentions an overview of the responses and actions towards this issue from international community. Second, it elaborates the Human Security explanation on Rohingya case; how does Human Security as a study sees this conflict? This section critically analyzes the case using academic writings on Human Security as the framework of thinking. Third, it briefly recommends what can IR actors other than state can do in helping the Rohingya people or even bigger in solving the issue itself.

\section{Rohingya: A Portrait of Human Insecurity}

The Rohingya are the descendants of Arab Muslims traders who live in Arakan (Rakhine state). They came mostly at the beginning of the 7th century and share the Arakan with the Buddhist people. Rohingya is claimed as the Bengali people who illegally came from Bangladesh as the neighbor of Myanmar.

The history of the discrimination was initially started in 1978 when the 'Tatmadaw' (Burmese military) held a large census named 'Nagamin' (Dragon King). It was reported that the operation resulted in rapes, mass killings, and dismissals of the Rohingya from their land. 10,000 of Rohingya died, and more than 200,000 were forced to flee to Bangladesh" (Parnini 2013, 286). It was justified because the army was blaming the prior conflict in which extremist Muslim vandalizing Buddhist communities.

In 1982, Burma passed the Citizenship Law of 1982. It establishes a legal discrimination towards Rohingya citizenship. It states that there are 135 'national groups' within Burma that lived in the country before 1823 and only those groups that have been granted permanent citizenship. Nonetheless, The Rohingya is excluded because they are claimed as the illegal Bengali migrant who came after 1823. In other words, this is a legal document that starts and justifies the human insecurity of Rohingya in Myanmar. Even though, at that time the term 'Human Security' itself had not been found and established.

The implementation of this law results in the suffering of Rohingya. Obviously, there is no freedom from fear. When Myanmar was led by the military, they were threatened by the soldiers. The 'interesting' part was that these soldiers not only threatened the Rohingya because they were asked by the government but also because their needs were not fulfilled by the government. The fact that the 
government could not provide a proper allowance for 450,000 armies, made and allowed them to rob from the Rohingya (HRW 2000). Soldiers theft what can they possibly take from the Rohingya, from money even to chicken. Up to now, Rohingya has to pay a higher tax than the local Burmese. Not to mention, after the clash between (Muslim) Rohingya and the Buddhist monk and the Arakanese, their lives is not any more valuable. It was reported by the Human Rights Watch in 2013, that at least 70 Rohingya were killed during the massacre in Yan Thei village in Mrauk-U Township in 2012. These death people included 28 children which 13 of them were under age 5. Rohingya people said that at that time there were police and army soldiers, but they did not protect them.

"First the soldiers told us, 'Do not do anything, we will protect you, we will save you.' But later they broke that promise. The Arakanese beat and killed us very easily. The security did not protect us from them."

125,000 people were recorded as the internally displaced people (IDP) (HRW 2013). Some of them were Rohingya, the Muslims, and a few Arakanese. "The destruction also included of 4,862 structures covering 348 acres of mostly Muslim-owned residential property" (HRW 2013).

Clearly, there is also no freedom from want for the Rohingya. Burmese government closes all access for Rohingya to get education and employment. Education is only for the local Burmese, and they are forced to be labor instead. "Those who refuse or complain are physically threatened, sometimes with death, and that children as young as seven years old have been seen on forced labor teams" (HRW 2000).

In addition, Rohingya people are way far from freedom to live in dignity. As their citizenships are denied, then basically they have no rights in Arakan or even Myanmar. It also means that the Rohingya are subjected to abuses, including discriminatory on access to education and employment, and restriction on property and movement (HRW 2000). Rohingya are not allowed to travel within or outside Arakan freely. They have to get 45 days permit if they want to do so. However, even to get the permit, it is hard for them. Not to mention that this permit also comes under complex conditions. It is followed by the heavy fines around US $\$ 29$ and detention for those violates the requirements (HRW 2000). It creates corruption as well because Rohingya people do not have any other option to get the travel documents except to bribe.
Further, Rohingya now is claimed as the world's largest group of stateless people for about 1.1 million (Mclaughlin 2015). Their insecure live in Arakan pushed them to move to find a safer shelter. In January 2009, it was captured that there were boats of Rohingya approach Thai and Indonesia shore line. The boats consisted of estimated at 6,000 people of Rohingya departing from Bangladesh and Burma (HRW 2009). However, Thai navy ships towing them back into the open seas to deter more illegal arrivals. Thailand, Indonesia, and Malaysia have been the three countries that are destined by the Rohingya traffickers and smugglers (Numan 2015).

Rohingya case is different compared to other human insecurity case. It is because this is a conflict between state and stateless. State that according to Human Security concept should protect and empower the people within turns out to coincidentally threaten and made them stateless. Their statelessness makes the condition worst because then it means they have nowhere to be sent back. This is unlike Syrian refugees. Syrian refugees have citizenship. Hence, they can always be sent back to Syria. However, that would not be the same with Rohingya because they are stateless.

Agreed that this case violates the human security, attention, and responses towards this issue have come abundantly. 1991 annual resolutions that were released by the UN General Assembly had condemned Burma's actions against the Rohingya (HRW 2013). Burma also has to approve the investigations and reports into human rights abuses throughout the 1990s held by UN Special Rapporteur on Human Rights (Crossman 2014, 44). In 2014, a resolution on Burma by the UN General Assembly was released. It calls the Burmese government to amend the 1982 Citizenship Law so that it no longer discriminates against the Rohingya (HRW 2015). "Burma's discriminatory citizenship law not only deprives Rohingya of citizenship but for decades has encouraged systematic rights violations," said Adams, the Human Rights Watch Asia Director (HRW 2015).

In addition, even the efforts are claimed as failed; ASEAN had held several summits, multilateral grouping, or talks on this conflict. For example, "ASEAN Summit" in Thailand 2009 and "Bali Process for People Smuggling, Trafficking in Persons, and Related Transnational Crime 2009" (HRW 2009). Nevertheless, none of it reached a consensus. It is not only because the Burmese government unwillingness to peacefully solve this case, but also ASEAN itself adopt the noninterference norm since 1967. Hence, there is not much that can be done towards this issue since the Burmese government itself has no willing to 
solve and no significant pressure such interference that can be done.

The bilateral approach had also been done. In 1992, a Memorandum of Understanding between Burma and Bangladesh had been signed (Crossman 2014 , 44). It obliged Burma to accept the return of Rohingya refugees who could prove their previous residence in the country. Nevertheless, their proof of residence has always been denied. Warns and talks had also been done by Indonesia and Malaysia to approach this issue (Al Jazeera 2015). Indonesia and Malaysia even agreed to shelter an estimated 7000 to 8000 Rohingya migrants from Myanmar and Bangladesh until they are either resettled in a third country or repatriated within a year (Cochrane 2015).

That is how this conflict goes. It keeps continuing and never improved. It persists for 38 years like something has never been done to solve. Meanwhile, the world has agreed that this is a violation of human security and this is a case of human insecurity.

\section{What Does it Tell Us?}

As it is mentioned earlier, the concept of Human Security was established in an attempt to shift the security paradigm from the traditional one (statecentric) to the modern one (human-centric). Human security was born as a response to the fact that state as the protector failed to fulfill its security obligations and even sometimes become a source of threat (Commission of Human Security 2003, 1). It comes not to abandon the state security, but in fact, it is to complement the state security. "It concerns on the individual and community rather than state, it pays attention to the people's security including threats and conditions that have not always been classified as threats to state security, it accounts an expanded actors beyond the state, and it is not only protecting but also empowering the people" (Commission of Human Security 2003, 5-6). It has five fundamental principles: people centered, comprehensive, context specific, prevention oriented, protection and empowerment (UN Trust Fund for Human Security $2016,7)$. In short, Human Security concludes seven elements or even seven possible root causes you may call: economic, health, personal, political, food, environmental, and community (in)security (Trust Fund for Human Security 2016, 7). At the end, with human security acknowledgment and protection, people can live free with the freedom of fear, freedom from want, and freedom to live in dignity.
Having that as a definition of Human Security, this essay argues that, first, this conflict shows that state security is still prioritized compared to human security. It shows that state is still being the referent instead of the people which in this case is Rohingya refugees (Nicholson 2010, 85). Rohingya in ArakanMyanmar, the one that should be protected and considered as the victims, in this case, is seen the other way around. They are claimed as the threat not only by the Burmese government but also the host country government.

"If they break the law and land in Thailand, how can we take care of them? Where will the budget come from? That money will need to come from Thai people's taxes, right?" (Thai Prime Minister Prayuth Chan-Ocha, NPR 2015)

"We will try to prevent them from entering our
territory. Otherwise it will create social issues, "If
we open up access, there will be an exodus here."
(Indonesia's military chief Gen. Moeldoko, The
Guardian 2015)

"What do you expect us to do? We have been very nice to the people who broke into our border. We have treated them humanely, but they cannot be flooding our shores like this." (Malaysian Deputy Home Minister Wan Junaidi Jafaar, The Guardian 2015)

It is true that refugees are protected by the International Human Rights Law and also international legal regimes such as The 1951 UN Convention relating to the status of refugee and the 1967 Protocol (Nicholson 2010, 84). However, as the international order is anarchy (Waltz 1979, 88-99) and that means no one above state, such legal regime is still less effective without states willing to be the executor. In fact, Australia government that signed the 1951 UN convention on refugees refused to accommodate Rohingya refugees (Topsfield 2015). That means human security is still marginalized compared to national interest including national security.

In addition, the fact that there has not been a call for securitization does strengthen the argument that human security is marginalized compared to state security. Meanwhile, given the overview earlier, this conflict is indeed a violation towards human security values that is held legally by a state (Myanmar). Logically, a securitization should be called by the leaders by the state in the region as they are the ones that own the privilege to do so (Watson $2011,4)$. Factually, they "ping-pong" the Rohingya who come for asylum from one shore to another 
shore line (Phil Robertson of Human Rights Watch quoted in The Guardian 2015).

Second, this conflict shows that human insecurity cases is interconnected. It could create more problems either by the domino effect or snowball effect. In Rohingya case, the domino effect is shown by how stateless cause the other insecurity such as no access to education (personal insecurity) and employment (economic insecurity), threatened by the local people (community insecurity), etc. Their statelessness and discrimination that they got push them to move illegally, either trafficking or smuggling. Surely, this is also another additional problem. Not to mention when they are drifted on the sea from one shore to another shore line, Rohingya people on the boats may die because of starving and the extreme condition. In addition, the snowball effect is shown by not only the Rohingya case itself that getting bigger, from the citizenship to population movement, but also the scope is getting wider. Rohingya conflict that was started only in Arakan, Myanmar now involves not only the Bangladesh the neighboring state but also regional area like ASEAN countries and Pacific (Australia). At first, it was an ethnic violence, but now it is a state violence (Abrar 2013, 3)

Last, this conflict implies that Human Security is still on the conceptual and or normative level instead of policy level. The fact that this conflict is also about ethnic conflict shows that Human Security is not a familiarized term within a society. True, that ethnic conflict must be a complex one. However, the fact that the local people of Burma do not humanize the Rohingya shows that Human Security has not touched the individual in the grassroots. In addition, this case shows that Human Security as a study and normative has not integrated with Human Security as a policy, especially in this Rohingya case. This implies that Human Security is still limited as a campaign rather than a "soul" (implementation).

\section{What Can We Do?}

Nowadays, any issue in the world can be a global challenge as we are living in the globalization era where everything is connected one to another. We have learnt that even human insecurities are interconnected. Thus, when we talk about the solution or at least "what can we do" then it needs complex approach that requires many stakeholders. It is not only limited to the state or regional/international organization/forums, but also to the individuals, Non-Governmental organizations, academicians (universities), etc.
This section specifically will not recommend what state and governmental organization can do. This paper has explained earlier how they actually had tried to solve this issue years ago but ended up with nothing. Their attempts to solve this issue remains zero result if they keep lacking of humanity commitment and political will to actually walk the talk; the talk that they actually have agreed in those resolutions and forums.

Therefore, this essay will briefly recommends what academicians (universities), individuals, and NGOs can help. For academicians or universities, the help can be by keep informing and educating the students through academic lecturer, seminars, or academic writings. This issue is not only for International Relations students or department, but also for health, economy, sociology, psychology or any other students or departments as this insecurity issues are interconnected. The more people studying or aware of this issue the more people or stakeholders can help. For individuals, the help can be keep informing ourselves to the issue so we know how to help itself; in what capacity we are able to help. It can be through donating or volunteering through governmental or non-governmental flags. Concrete example is just like how people in Aceh pulled the illegal Rohingyan asylum seeker' boat to their coast and quickly evacuated them (BBC News 2020). Last, for NGO the help can be through volunteering on their camp site, gathering and giving them donations in any form of donations, or even better by advocating their rights through media or forums nationally and globally. Finally, this issue cannot be solved alone whether alone in terms of approach or in terms of the actors. It is our commitment together that human security is everyone' rights.

\section{Conclusion}

If Human Security is translated as the "freedom from fear, freedom from want, and freedom to live in dignity," then these what Rohingya people search for. The fact that state should be the one who responsible for its citizen's security does not imply at all in the Rohingya case. For 38 years, they have been stateless. They are legally discriminated by the people and the government where they lived and been "ping ponged" (pushed back and forth) in the Southeast Asia Sea whenever they seek for asylum.

This essay argues that at least there are three explanations that Human Security as a study can infer as well as criticize. First, it is still about the sovereignty over humanity. Rohingya case shows the 
condition which state security is still prioritized more than human security. Second, this conflict shows the interconnected-ness of human insecurity cases either by the domino effect or snowball effect. Last, this conflict is a portrait that Human Security is still in the conceptual and or normative level rather than policy level. Meanwhile, the integration of them will be greater in a way that Human Security is not only a campaign and a goal but also a soul of the international system. At the end, this essay recommends some ideas that we (academicians (universities), individuals, and NGOs) can do to help or even better to contribute in solving this issue.

\section{Reference}

Abrar, C.R.. 2013. Multilevel Approaches to Human Security and Conflict Management: The Rohingya Case. Singapore: Rajaratnam School of International Studies.

Bali, Sita. 2008. "Population Movements." In Contemporary Security Studies, edited by Alan Collins, 468-482. Oxford, UK: Oxford University Press.

BBC News Indonesia. 2020. "Rohingya: 94 Pengungsi Yang Terombang Ambing di Laut Dibawa ke Daratan Aceh Atas Dasar Kemanusiaan." BBC News Indonesia, June 2020. Acesses August 12, 2020.

https://www.bbc.com/indonesia/indonesia$\underline{53160292}$

Cochrane, Joe. 2015. "In Reveal, Myanmar Agrees to Attend Meeting on Migrant Crisis." The New York Times, May 2015. Accessed October 23, 2015.

http://www.nytimes.com/2015/05/22/world Lasia/myanmar-rohingya-migrant-crisismalaysia-thailand-indonesia.html? $\mathrm{r}=0$.

Commission on Human Security. 2003. Human Security Now. New York: Commission on Human Security of United Nations.

Crossman, Linda. 2014. "Myanmar's Rohingya Refugees: The Search For Human Security." Master Thesis, Georgetown University.

Gomez, Oscar A., and Gasper, Des. n.d. United Nations Development Program Human Development Report Office. New York: UNDP.

Human Rights Watch. 2000. "Human Rights Report: III. Discrimination in Arakan." Accessed October 202015. https://www.hrw.org/reports/2000/burma/ burm005-02.htm\#P152 44559.

Human Rights Watch. 2009. "Burma: End Abuses Against Rohingya." Accessed October 222015. http://www.hrw.org/news/2009/05/25/bur ma-end-abuses-against-rohingya.

Human Rights Watch. 2009. "Perilous Plight." Accessed October 222015. http://www.hrw.org/report/2009/05/26/pe rilous-plight/burmas-rohingya-take-seas.

Human Rights Watch. 2013. "All You Can Do is Pray." Accessed October 202015. https://www.hrw.org/report/2013/04/22/al l-you-can-do-pray/crimes-against-humanityand-ethnic-cleansing-rohingya-muslims.

Human Rights Watch. 2013. "Burma: Amend Biased Citizenship Law." Accessed October 202015. https://www.hrw.org/news/2015/01/13/bu rma-amend-biased-citizenship-law.

Human Rights Watch. 2013. "Burma: End 'Ethnic Cleansing' of Rohingya Muslims." Accessed October 202015. https://www.hrw.org/report/2013/04/22/al l-you-can-do-pray/crimes-against-humanityand-ethnic-cleansing-rohingya-muslims.

Human Security Unit of United Nations. 2014. Strategic Plan 2014-2017. New York: Human Security Unit of United Nations.

Mclaughlin, Timothy. 2015. "Myanmar to send home 200 fleeing Bangladeshis: report.” The Sydney Morning Herald, May 2015. Accessed October 17 2015. http://www.smh.com.au/world/myanmar-tosend-home-200-fleeing-bangladeshis-report20150526-gh9xjv.html.

Neuman, Scott. 2015. "Why No One Wants The Rohingyas." National Public Radio, May 2015. Accessed October 24, 2015. http://www.npr.org/sections/thetwoway/2015/05/15/407048785/why-no-onewants-the-rohingyas.

Newman, Edward. 2010. "Critical Human Security Studies." Review of International Studies 36: 7794.

Nicholson, Frances. 2010. "Protection and Empowerment: Strategies to Strengthen Refugees' Human Security. In Human Security and Non Citizens, edited by Alice Edwards and Carla Ferstman, 82-124. Cambridge: Cambridge University Press.

n.n. 2015. "Malaysia and Thailand Turn Away Hundreds on Migrant Boats." The Guardian, May 2015. Accessed October 172015. http://www.theguardian.com/world/2015/m ay/14/malaysia-turns-back-migrant-boatwith-more-than-500-aboard.

n.n. 2015. "UN and Myanmar Spar Over Rohingya at Migrant Talks.” AlJazeera, May 2015. Accessed 
October

http://www.aljazeera.com/news/2015/05/th

ailand-hosts-talks-regional-migrant-crisis150529032927779.html.

Parnini, Syeda Naushin. 2013. "The Crisis of The Rohingya As A Muslim Minority in Myanmar and Bilateral Relations with Bangladesh." Journal of Muslim Minority Affairs 33 (2): 281297.

Topsfield, Jewel. 2015. "Indonesia to Australia: 'You Signed the UN Convention on Refugees. Act on It." The Sydney Morning Herald, May 2015. Accessed October 23, 2015. http://www.smh.com.au/federalpolitics/political-news/indonesia-to-australiayou-signed-the-un-convention-on-refugeesact-on-it-20150521-gh6u58.html.

UN News Centre. 2013. "Failure to address discrimination could undermine reforms in Myanmar." Accessed October 222015. http://www.un.org/apps/news/story.asp?Ne wsID=45215\#.Viv5VLcrLIV.

UN Trust Fund for Human Security. 2016. "Human Security Hnadbook". Acessed August 12, 2020. https://www.un.org/humansecurity/wpcontent/uploads/2017/10/h2.pdf

Waltz, Kenneth N. 1979. Theory of International Politics. Long Grove, IL: Waveland Press, Inc.

Watson, Scott. 2011. “The 'Human' as a Referent Object? Humanitarianism as Securitization." Security Dialogue 42 (1): 3-20.

Wolf, Siegfried O.. 2015. "The Rohingya: Humanitarian Crisis or Security Threat." The Diplomat, October 2015. Accessed October 20, 2015. http://thediplomat.com/2015/10/therohingya-humanitarian-crisis-or-securitythreat/. 